ПРИМОВА Эльмира Неджефовна - кандидат исторических наук, ведущий научный сотрудник Научно-исследовательского института Академии Генеральной прокуратуры РФ (123022, Россия, г. Москва, 2-я Звенигородская ул., 15; primova@inbox.ru)

\title{
О НЕКОТОРЫХ ОСОБЕННОСТЯХ АДМИНИСТРАТИВНОГО УСТРОЙСТВА РЕСПУБЛИК СКФО
}

Аннотация. В статье автор предпринимает попытку выявить и проанализировать некоторые изъяны и недостатки национально-территориальной формы административного устройства национальных республик Северного Кавказа, которые служат одним из факторов все еще сохраняющейся конфликтогенности региона. Автор обосновывает тезис, что в сложившихся в регионе условиях этот принцип устройства изжил себя и нуждается в серьезной переоценке. Главную цель такой переоценки автор видит в постепенном отказе от этнотерриториального принципа и переходе к общему для всей Российской Федерации государственно-административному принципу, а при выборе высших руководителей законодательных и исполнительных органов республиканских властей - от этнических критериев к критериям профессионализма.

Ключевые слова: Российская Федерация, Северный Кавказ, федерация, субъект федерации, политика, власть, национальная республика, этнотерриториальный принцип, административно-территориальный принцип

$\Pi$ реимущество федеративной формы государственного устройства состоит в том, что она обеспечивает благоприятные условия для социального, экономического, политического, конституционно-правового единства страны. Этот критерий имеет особую значимость для такой страны, как Россия, с разнообразными регионами, которые более или менее существенно различаются между собой природно-географическими характеристиками, многонациональным составом, разными уровнями социально-экономического и культурного развития и др.

Выбор оптимальных форм, путей и механизмов взаимоотношений федерального центра и субъектов федерации в многонациональном государстве, каким является Российская Федерация, представляет собой весьма сложную и трудноразрешимую задачу. В современном мире жизнеспособность и эффективность федеративного государства в важнейших сферах общественной жизни гарантируются при органическом сочетании горизонтального разделения полномочий между тремя ветвями власти с вертикальным разделением полномочий между тремя ветвями власти в отношении предмета ведения между федеральным центром и субъектами федерации.

С этой точки зрения большое значение имеют принципы организации административного устройства федерации. Как известно, существуют три таких принципа, характерных для мононациональных и многонациональных федеративных государств: административно-территориальный, этнотерриториальный и смешанный, сочетающий в себе оба ранее названных принципа. Выбор какого-либо одного их них зависит от комплекса национально-исторических, этнонациональных, духовных, социокультурных и целого ряда других связанных с ними факторов. Большинство федеративных государств, в т.ч. некоторые многонациональные, построены на административно-территориальной основе, что как бы выводит за скобки национальный или этнический фактор. 
Очевидно, что федеративная форма государственного устройства призвана обеспечить политико-правовое равноправие всех без исключения народов соответствующей страны. Как известно, для многонационального государства этнотерриториальный принцип устройства рассматривается в качестве наиболее приемлемого выбора с точки зрения решения национального вопроса. Но, как показывает мировой опыт, этот принцип не всегда и не обязательно обеспечивает решение данной задачи и во многих случаях способен служить фактором, стимулирующим противоречия и конфликты и, соответственно, подрывающим единство и территориальную целостность федеративного государства. В этом контексте преимущество административно-территориального устройства состоит в том, что оно призвано учитывать прежде всего ресурсные, социальные, экономические, технологические, региональные и иные факторы, как бы выводя за скобки этнонациональный. Обоснованность данного тезиса подтверждается опытом таких в целом стабильных с точки зрения сохранения единства государств, как Австралия, Австрия, Аргентина, Бразилия, США, ФРГ и др., которые выбрали территориально-административный принцип устройства федерации.

В большинстве многонациональных государств, как правило, федерация базируется либо на этнотерриториальном, либо на смешанном принципе. При этнотерриториальном принципе главное место отводится территориальным границам расселения соответствующих этносов, фактически как бы выводя за скобки другие не менее значимые факторы, такие, например, как экономика. Однако реальное положение вещей в России весьма далеко от теории. Для правильного понимания неоднозначности решения данного вопроса представляется целесообразным привести примеры Швейцарии и Бельгии.

Многовековой опыт Швейцарской конфедерации, которая при всех исторических трансформациях смогла сохранить свое единство и жизнеспособность, обеспечить социальное и экономическое процветание, свидетельствует о преимуществах данного принципа самоорганизации федерации. Однако существует целый ряд примеров, свидетельствующих, что этнотерриториальный принцип федеративного устройства не всегда и не обязательно демонстрирует способность успешно и окончательно решить весьма важный для многих стран национальный вопрос и, соответственно, проблемы обеспечения социальной и политической стабильности, а также единства страны.

Так, Бельгия из унитарного государства в 1980 г. была преобразована в федерацию, состоящую из трех культурно-языковых сообществ: фламандского (Фламандский округ), франкоязычного (Валлонский округ и Брюссельский столичный округ); немецкоязычного (часть провинции Льеж). Было бы не совсем корректно утверждать, что руководству этой страны путем такой перекройки удалось сколько-нибудь успешно решить межнациональные противоречия. Дело в том, что в последние годы бельгийская федерация переживает довольно серьезный кризис, вызванный противоречиями между двумя главными культурно-языковыми общинами - фламандцами и валлонами, порой доходящий до угрозы распада страны на две части.

Наиболее очевидные примеры неудачи и несостоятельности данного принципа представляют примеры распада Чехословакии, Югославии и СССР в 90-х гг. прошлого века. С рассматриваемой точки зрения особенность РФ состоит в том, что она выбрала смешанный принцип, унаследованный от СССР, и включает в свой состав субъекты, представляющие этнотерриториальные образования (республики, автономные области, автономные округа) и административно-территориальные образования (края, области, города федерального значения). 
С рассматриваемой точки зрения большой интерес представляет опыт Северного Кавказа. В советский период административное устройство СевероКавказского региона приобрело форму «этнотерриториального представительства». В результате создалась довольно сложная и противоречивая система, при которой каждый отдельно взятый народ стал неотъемлемой частью единой наднациональной советской общности. И в то же время политика так называемой коренизации народов создавала условия для формирования их самосознания. Как отмечает Р.М. Эмиров, «хотя эти народы были лишены фактического политического суверенитета, им была гарантирована определенная территориальная идентичность, национально-образовательные и культурные институты, что обеспечивало условия для развития наций и этносов, их культур, языков и традиций» [Эмиров 2012: 19].

Нельзя не признать, что выделение национальных автономий в самостоятельные единицы государственно-административного устройства СССР действительно сыграло позитивную роль в плане их экономического, социального, политического, культурно-языкового развития. Государственная национальная политика и советская наука, при всем интернационализме, по сути дела, заложили основы формирования и институционализации этничности. В этнографической науке всячески поощрялось выделение культурно-языковых различий народов, их этнотерриториальной и культурно-языковой идентичности, порождающих, в свою очередь, стремление к обретению собственной государственности. Поэтому не удивительно, что этот принцип стал своего рода бомбой замедленного действия, заложенной под единство СССР. Проблема состояла в том, что уже к 1980-м гг. он окончательно изжил себя и сохранялся только в силу исторической инерции. Названия всех так называемых национальных республик не соответствовали реальному положению вещей. Тем более они противоречат реалиям Российской Федерации. В результате тех процессов и тенденций, которые характерны для региона в последние десятилетия, административные границы национальных республик региона перестали соответствовать границам ареалов проживания многих народов, которые, особенно в городах, перемешались друг с другом. Эти границы оказались изломанными и изрезанными, а то и вовсе исчезли. Если Чечню и Ингушетию с абсолютным большинством автохтонного этноса условно можно назвать моноэтническими республиками, то этого никак не скажешь о других северокавказских субъектах РФ, которые по факту являются многонациональными. Более того, в некоторых республиках так называемый титульный народ, одноименное название которого они носят, составляет меньшинство по сравнению с другими народами. Например, в Республике Адыгея одних только русских, не считая представителей других народов, в 2,5 больше, чем самих адыгов. Моноэтничность сохраняется лишь в сельских районах, из которых значительная часть более или менее дееспособной молодежи постепенно переселяется в полиэтнические города.

В силу этих факторов права и интересы всех проживающих в регионе народов и этнонациональных групп настолько тесно переплетены друг с другом, что гарантировать защиту прав и интересов какого-либо одного из этих народов представляется невозможным без учета прав и интересов всех других. Поэтому нельзя не отметить искусственность административного разграничения некоторых субъектов федерации по якобы национальному признаку.

В отечественной научной литературе обоснованно указывалось на бесперспективность перекройки политической карты России по этнонациональному принципу и попыток создания чисто этнических государственных образований на основе этнонационализма. Разумеется, нельзя рассматривать существу- 
ющие между республиками административные границы на Северном Кавказе, да и в остальных регионах РФ, как некую неприкосновенную «священную корову». В этом плане интерес представляет появление как в научных и публицистических кругах, так и в структурах государственной власти разного рода проектов изменения административно-территориального устройства страны, в т.ч. Северного Кавказа, путем сокращения числа субъектов федерации.

Возможно, административно-территориальный принцип устройства федерации не всегда и не в должной мере способен решать в многонациональных государствах те или иные проблемы, возникающие в отношениях между различными этносами. В то же время, как уже отмечалось, попытки разрешения национального вопроса в таких государствах не всегда достигают успеха. Более того, в определенных условиях данный принцип может оказаться своего рода бомбой замедленного действия с точки зрения стимулирования межнациональных противоречий и конфликтов, доводящих до националсепаратизма.

В этом русле особо опасными представляются проекты объединения тех или иных народов, населяющих отдельные национальные республики, в некие моноэтнические республики в составе РФ. К примеру, среди определенной части интеллигенции северокавказских республик не потерян интерес к проекту, который еще в 2003 г. был выдвинут ведущей сотрудницей Адыгейского республиканского института гуманитарных исследований им. Т.М. Керашева Х.И. Тугуз. В нем предлагалось вывести из состава Кабардино-Балкарии кабардинцев и черкесов из состава Карачаево-Черкесии для объединения всех адыго-черкесских народов вместе с адыгами Республики Адыгея в самостоятельное государственное образование - Адыгскую Республику в составе Кабардинского (с центром в г. Нальчике), Адыгейского (с центром в г. Майкопе), Черкесского (с центром в г. Черкесске) автономных округов в составе РФ. Как считает Тугуз, по такой же схеме можно было бы объединить тюркоязычных балкарцев и карачаевцев Кабардино-Балкарии и КарачаевоЧеркесской Республики. По ее мнению, в перспективе возможно создание и других национально-государственных образований, например на основе этнического воссоединения вайнахов (чеченцев и ингушей), осетин, лезгин, ногайцев и др. [Тугуз 2003].

Однако подобные проекты лишены объективных оснований. Дело в том, что территории расселения народов, которые предлагается объединить в единое целое, не являются компактными. Особо важное значение с рассматриваемой точки зрения имеет тот факт, что в современных условиях информационной революции и глобализации, которые характеризуются преобладанием процессов и тенденций консолидации народов на путях формирования единой российской нации, попытки формирования моноэтнических этнократических государственных образований способны возвратить нас к ситуации так называемого парада суверенитетов начала 90-х гг. прошлого века. Совершенно прав B.А. Тишков, полагая, что «попытки восстановить историческую справедливость» приводят к новым несправедливостям уже в отношении современного населения. В рамках единого государства эти проблемы должны решаться на путях взаимного сотрудничества, свободы передвижения и проживания, развития экономических и гуманитарных связей, уважения индивидуальных и коллективных прав граждан» [Пути... 1999: 64].

В современных условиях этнотерриториальный принцип стал одним из ключевых факторов, препятствующих окончательному преодолению конфликтогенности региона. Более того, временно заглушая противоречия и конфликты между различными этносами, конфессиональными, культурно-языковыми 
сообществами, этот принцип во многих случаях существенно осложняет проблему обеспечения единства и территориальной целостности федеративного государства. С ним связан также такой феномен, как титульный народ, что на Северном Кавказе, где, по сути дела, имеет место своего рода вавилонское смешение народов, представляется недоразумением. Именно разделение населения северокавказских республик на автохтонное и неавтохтонное, на титульные и нетитутльные народы во многом обеспечивает фактическую легитимацию политического статуса региональных элит на этнической основе. А это, в свою очередь, ведет, если не публично, то фактически, в негласной форме, к иерархизации народов региона, их разделению на «равных» и «более равных». Об этом свидетельствует сложившаяся практика, при которой главами национальных субъектов РФ в обязательном порядке должны быть представитель автохтонного народа, хотя в конституции страны нет соответствующей статьи. Именно такое положение во многом оказывается основой легитимации региональных властных элит по этническому критерию, верховенства этнического принципа рекрутирования высших руководителей национальных республик согласно этнической принадлежности.

Очевидно, что сложившиеся реалии требуют более или менее существенной переоценки потерявших свою жизнеспособность практик рекрутирования высших должностных лиц, руководителей законодательных и исполнительных органов национальных республик Северного Кавказа и перевода их в конституционно-правовое поле РФ. Главной целью такой переоценки представляется постепенное внедрение приоритетов профессионализма независимо от национальной, конфессиональной, культурно-языковой, половой и иной принадлежности всех без исключения претендентов на место во властной системе северокавказских субъектов Российской Федерации.

\section{Список литературы}

Пути мира на Северном Кавказе: независимый экспертный доклад (под рук. В.А. Тишкова). 1999. М.: Изд-во Института этнологии и антропологии РАН. $184 \mathrm{c}$.

Тугуз Х.И. 2003. Региональная федерация: Юг России и проблемы развития. - Федерализм на Юге России. Ростов н/Д. С. 128-134.

Эмиров Р. 2012. Перспективы реформирования национально-территориального устройства Северного Кавказа. - Юридический вестник ДГУ. № 1. С. 18-21.

PRIMOVA Elmira Nedzhefovna, Cand.Sci. (Hist.), Leading Researcher at the Scientific Research Institute of the Academy of the Prosecutor General's Office of the Russian Federation (15 $2^{\text {nd }}$ Zvenigorodskaya St, Moscow, Russia, 123022; primova@inbox.ru)

\section{ABOUT SOME ASPECTS OF THE ADMINISTRATIVE DIVISION OF THE NORTH CAUCASIAN FEDERAL DISTRICT REPUBLICS}

Abstract. In the article, the author attempts to identify and analyze some flaws and shortcomings of the national-territorial form of the administrative structure of the national republics of the North Caucasus, which serve as one of the factors of the region's conflict potential. The author substantiates that in the conditions prevailing in the region this principle has outlived its usefulness and needs a serious reassessment. The author sees the main goal of such a reassessment in the gradual abandonment of the ethno-territorial principle to the state-administrative principle common for the entire Russian Federation, 
and when choosing the top leaders of the legislative and executive bodies of the republican authorities the author suggests switching from ethnic criteria to the criteria of professionalism.

Keywords: Russian Federation, North Caucasus, federation, constituent entity, politics, power, national republic, ethnoterritorial principle, administrative-territorial principle

ОЗЕРОВ Александр Алексеевич - кандидат философских наук, доцент кафедры философии и религиоведения Военного университета Министерства обороны РФ; доцент департамента социологии, истории и философии Финансового университета при Правительстве РФ (125993, Россия, г. Москва, ГСП-3, Ленинградский пр-кm, 49; aоzerov@сатрus.muh.ru)

\section{СМЫСЛОЖИЗНЕННЫЙ КОМПОНЕНТ РОССИЙСКОГО СОЦИУМА В УСЛОВИЯХ ПАНДЕМИИ COVID-19}

Аннотация. Статья посвящена рассмотрению социологического аспекта смысложизненного компонента в контексте пандемии COVID-19. Рассматривая особенности состояния социума в период серьезных режимных преобразований в условиях распространения коронавирусной инфекции, автор выделяет индивидуальное и социальное измерения поисков проблемы смысла существования и существенное внимание уделяет исследованию внутриличностных особенностей понимания смысла существования в период кризиса.

Ключевые слова: философия, кризис, социология, психология, смысл жизни, личность

П роблема смысла жизни является актуальной во все исторические эпохи. Смысл существования искали как во времена всеобщего благоденствия, так и в периоды войн и революций, во времена эпидемий и пандемий. Особенно важное звучание данная проблема приобретает в кризисные этапы исторического развития, когда индивид невольно начинает искать причины негативных явлений в окружающем мире или в собственной личности.

Внезапно обрушившаяся на мир пандемия коронавируса, поражающая организм не только человека, но и некоторых животных [Шеметова и др. 2020: 209], оказала серьезное влияние на осмысление мира среднестатистическим человеком. Более того, данная проблема заставила также задуматься о будущем видных политиков и крупных бизнесменов, известных врачей и ученых с мировым именем.

Коронавирусная пандемия затронула практически все социальные слои России - сначала тех, кто был склонен путешествовать и оказался в странах, где было наибольшее число зараженных, а в дальнейшем эта проблема коснулась и рядовых жителей страны.

Не проходит и дня, когда бы не публиковались новости по теме пандемии и не приводилась бы статистика числа умерших от коронавируса и уже излечившихся. К счастью, в настоящее время можно наблюдать, что некоторые страны открываются, число исцелившихся увеличивается и ограничения постепенно снимаются. Но еще совсем недавно коронавирус порождал многочисленные теории заговоров и, казалось бы, давно забытые «пророчества» научной фантастики. Продолжает расти число фейковых новостей, вносящих рознь и неуверенность в российское общество. Вполне можно согласиться с А.В. Клеминым, 